\title{
FEARS AND CONCERNS RELATED TO MENSTRUATION: A QUALITATIVE STUDY FROM THE PERSPECTIVE OF GENDER
}

\author{
Alicia Botello-Hermosa ${ }^{1}$, Rosa Casado- Mejia ${ }^{2}$
}

\footnotetext{
${ }^{1}$ Ph.D. in women's and gender studies. Professor at the Faculty of Nursing, Physiotherapy and Podiatry at the University of Seville Seville, Spain. E mail: abotello@us.es

${ }^{2}$ Ph.D. in women's and gender studies. Professor at the Faculty of Nursing, Physiotherapy and Podiatry at the University of Seville Seville, Spain. E mail: rcasado@us.es
}

\begin{abstract}
The aim of this article is to analyze the fears about menstruation and health that have been passed down to us by oral transmission from a gender perspective. A qualitative study, whose design was the Grounded Theory, performed in Seville, Spain, with 24 rural and urban women from different generations, young (18-25, 26-35 years), middle aged (36-45, 46-55, 56-65 years) and elderly ( $>65$ years). The semi-structured interview was used as a data collection technique. The discourses were subjected to content analysis, following the steps of Grounded Theory. The results highlight the abundant fears related to use of water during menstruation, with very harmful effects to health. As a conclusion to highlight the lack of women's knowledge about reproductive health and that despite Health Education campaigns there are still ancient misconceptions present about menstruation.
\end{abstract}

DESCRIPTORS: Menstruation. Gender identity. Qualitative research. Women. Nursing.

\section{MIEDOS Y TEMORES RELACIONADOS CON LA MENSTRUACIÓN: ESTUDIO CUALITATIVO DESDE LA PERSPECTIVA DE GÉNERO}

\begin{abstract}
RESUMEN: El objetivo del artículo es analizar los miedos sobre la menstruación y la salud que han llegado hasta nuestros días mediante transmisión oral desde la perspectiva de género. Estudio cualitativo, cuyo diseño fue la Teoría Fundamentada realizado en Sevilla, España, con 24 mujeres de medio rural y urbano de diferentes generaciones jóvenes (18-25, 26-35 años), mediana edad (36-45, 46-55, 56-65 años) y mayores (>65 años). Se utilizó como técnica de obtención de datos la entrevista semi-estructurada. Los discursos fueron sometidos al análisis de contenido, siguiendo los pasos de la Teoría Fundamentada. Como resultados destacar abundantes miedos relacionados con el uso del agua durante la menstruación, con efectos muy perjudiciales para la salud. Como conclusiones destacar la falta de conocimientos de las mujeres en la salud reproductiva ya que a pesar de las campañas en Educación para la Salud todavía siguen presente creencias erróneas milenarias sobre la menstruación.
\end{abstract}

DESCRIPTORES: Menstruación. Identidad de género. Investigación cualitativa. Mujeres. Enfermería.

\section{MEDOS E RECEIOS RELACIONADOS COM A MENSTRUAÇÃO:ESTUDO QUALITATIVO A PARTIR DA A PERSPECTIVA DE GÉNERO}

RESUMO: O objetivo do artigo foi analisar os medos sobre a menstruaçao e a saúde que chegaram até aos nossos dias através da comunicação oral, numa perspectiva do género. Um estudo qualitativo, cujo desenho se baseou na Teoria Fundamentada nos Dados, realizado em Sevilha, Espanha, tendo como base 24 mulheres de meio rural e urbano de diferentes gerações, jovens (18-25, 26-35 anos), de meia idade (36-45, 46-55, 56-65 anos) e idosos (>65 anos). Utilizou-se como técnica de obtenção de dados a entrevista semiestruturada. Os dados foram submetidos a uma análise de conteúdo, seguindo os passos da Teoria Fundamentada. Dentro dos resultados, destacamos os abundantes medos relacionados com o uso de água durante a menstruação, com efeitos muito prejudiciais para a saúde. Destacamos a falta de conhecimento por parte das mulheres na saúde reproductiva ja que, apesar das campanhas no âmbito da Educação para a Saúde, continuam presentes crenças milenares erradas sobre a menstruação.

DESCRITORES: Menstruação. Identidade do género. Investigação qualitativa. Mulheres. Enfermagem. 


\section{INTRODUCTION}

The present article is part of a broader research from a doctoral thesis whose purpose was to study the popular beliefs and social representations about the life cycles of women from a gender perspective and from the "voice of the interviewees". Each society stipulates what attributes are stereotypically masculine or feminine, considering therefore that there are gender roles depending on whether you are a man or woman. ${ }^{1}$

The basic distinction by which sex and gender are defined, is that sex is determined by the sexual difference inscribed in the biological body, whereas gender is related to the meanings that each society attaches to specific physical traits. It is used to describe the characteristics of women and men that are based on social factors, while sex refers to the biologically determined characteristics. Therefore, it is very important to emphasize that the ways of behaving, thinking and feeling of both sexes, rather than having a natural and unchanging base, are due to social and family structures assigned differentially to women and men. These patterns of mental and social configuration lead to femininity and masculinity and thereby to gender roles. ${ }^{2}$

With regard to life cycles in general and menstruation in particular, these are ideas, beliefs and practices that some women have so internalized that they can either help them live better or, on the contrary, limit their own lives and those of their families.

The menstrual cycle is a multidimensional phenomenon since a whole series of reciprocal influences that are not only biological or psychological, but also social and cultural are given in it. This explains the need to consider the analysis of those psychosocial aspects that converge within it, studying, apart from the biological functions, the psychological, anthropological and cultural aspects of the cycle which are the least studied due to the difficulty for us to move within personal and subjective grounds. The menstrual subculture contains language, health tools, social norms, expectations and beliefs about how women should feel, act, behave, etc., during the menstrual cycle. It is important to study and understand these social and cultural aspects, as it has been explained that there is a certain inability of emotional, physical and cognitive type during some phases of the menstrual cycle in performing tasks of responsibility. In this case, a biological origin to a number of biases that are used to try to separate women from certain spheres of power and social control was sought. ${ }^{3}$

The exposure of women to cultural norms about health in general and especially menstruation creates a set of ideas, opinions and expectations that influence how they experience and qualify their own feelings during menstruación. ${ }^{3}$

We begin from the idea that health and illness, and therefore the life cycles, are presented under an encoded symbolic reference frame, resulting in specific practices and behaviors, supported by rooted myths, beliefs and customs. ${ }^{4}$ In addition, the gender condition must be added to this premise that arises in these situations leading to different connotations with respect to human care, the care that requires physical strength and control of public order being assigned to men, while women are given the care related to all their life and privacy. ${ }^{5}$

The collective beliefs and attitudes towards the menstrual cycle not only appear to be involved in what women experience but are used as explanations for female behavior. In fact, contamination hazards have always been attributed to menstrual blood that justify the rigidity with which women put economic, political or religious activities aside. $^{6}$

The presence of blood gives a special symbolism to this physiological process, as blood has emotional evocations, symbols and rituals for all cultures, which range between life and death; associating its abundance to life, health and its loss to disappearance, illness and death. ${ }^{6}$

As the purpose of the research was to determine which fears currently exist in Sevillian women about menstruation from the gender perspective, the study line considered was the analysis of gender determinants in health, as what is proposed to analyze is the social models, roles and identities that are associated.

The theory of Social Representations, defined by a set of concepts, propositions and explanations that originate in daily life and during interpersonal relationships, as well as allowing us to create information and familiarize ourselves with the unknown through the processes of objectification theory and anchorage was used 
as a reference, recognizing the common sense explanations of the individuals in a community through their myths, traditional knowledge systems and beliefs. ${ }^{7}$

It is emphasized that the study of social representations involves analyzing and understanding different areas that work interdependently: language, thought and behavior. Language is the best example of symbolic system, as social reality is collectively constructed from it. ${ }^{8}$

For this reason, some authors think that language is the most important explanatory element of everything social. ${ }^{9}$ The recognition of the functions of language and its importance in the construction of social realities allows us to generate a framework for interpreting different discourses by women regarding their life cycles and different practices derived from them.

Therefore, the Theory of Social Representations allows us to know what representations women have regarding their menstrual cycle, since the objectification can materialize the word by transforming an abstraction into the concrete, physical and tangible and the anchoring cognitively integrates the object represented to a system of existing social thought that is revealed in the language of the people who share the same social group, conditions and experiencias. ${ }^{5}$

Consequently, recognizing a social representation involves determining what is known (information), what is believed, how it is interpreted (field of representation) and what is done or how it acts (attitude). Attitude is the most affective aspect of representation. It is the most primitive and resilient element and is always present although other elements are not. That is, the emotional reaction that can be had by a person or a group without the need of having more information on the fact to study. ${ }^{10}$

In addition, so that a social representation is produced, it is necessary to consider the scenario of everyday life, because that is where the events are seen that will subsequently become the definitive representations of something or someone. ${ }^{11}$

The aim of the research was to know what fears currently exist in our society in Sevillian women of different generations and have been passed down to us through oral transmission. And as specific objectives to determine what they know about menstruation, what representations they have about it and how they act or acted during the days of menstruation.

\section{METHOD}

A study of qualitative empirical nature ${ }^{12}$ with methodological framework of Grounded Theory (GT). As the fears about menstruation was the aim of the study, research was of a qualitative type ${ }^{13}$ since it allows us to understand the world of subjective experience from the point of view of people who live it. Thus, this paradigm does not focus on the prediction and control of a phenomenon (study of variables), but on the systematic description of everyday experience. ${ }^{14}$

Age groups were decided as from the specific population, women: young (18-25 years, 2635 years), middle aged (36- 45 years, $46-55$ years, $56-65$ years) and elderly (> 65 years). Age was established as segmentation criteria because, as it is a study on women's life cycles, we were interested in their opinion about this according to the stage they were living, besides comparing the possible age-related beliefs. Another criterion was the location: rural or urban area. It was intended to compare the level of popular beliefs and study whether they are more abundant in rural areas than in urban areas.

A total of twenty four semi-structuredinterviews was performed, twelve in urban and twelve in rural areas to women in the age ranges set forth above. Two informants per profile were used. A questionnaire of 13 open questions was designed for research following the criteria of qualitative research (COREQ) ${ }^{15}$ related to menstruation (beliefs, prohibitions, fears, metaphors). Prior to the interviews, the informants were asked for their verbal informed consent to record audio interviews for later transcription and they were informed of the objectives of the study, the use of information and anonymity to respect the ethical standards of research. The 24 interviewees agreed. The interviewees are indicated by the letter $M$ followed by the number of interview, R or U (rural or urban) and age. The 24 semi-structured interviews were carried out in different scenarios: Faculty of Nursing at the University of Seville, their workplace and at the homes of some interviewees. Each one lasted an average of 45 minutes.

Theoretical sampling is ideal when the main purpose of data collection is to gener- 
ate a substantive theory. It is continuous and gradual, guided by data collection, analysis and interpretation while establishing the theory. It is especially consistent with the objectives and PDT techniques. This was the one used in the research. The interviews were carried out between March 2008 and December 2011 in the province of Seville, Spain, and three Sevillian towns (La Rinconada, Ecija, and Osuna).

Within the profiles established according to the targeting criteria specified, other variables that should be present for their importance in the representation of the interviewees were defined. Educational level: to study how the level of education affects the existence or not of erroneous popular beliefs. The classification was performed according to the level of education they had in: uneducated (no academic degree), media studies (non-university academic degrees) and university studies (bachelor and master degrees). Likewise, university students were included at the university level; Mothers or women without children: the approach was to study whether women live their life cycle differently being mothers or women without children; Profession: housewives and women working outside home.

The analysis categories were: popular expressions and metaphors of language related to women's life cycles: expressions used and metaphors relating to stages studied are included, as well as cases of variations of the same metaphor in the different municipalities selected or due to the literature review. Whether language has evolved over time was also analyzed.

Gender: the gender category indicates the set of characteristics such as emotions, beliefs, personal traits, attitudes, values, norms and standards that define an established form of relationship between men and women, determine what is masculine and feminine, how and what women and men should be/do in each society.

Fears: fear or concern is an emotion identified by an intense unpleasant feeling caused by the perception of danger, real or fake, present, future or past. Terror is the ultimate expression of fear. Fear is also related to anxiety and the state of anxiety, which is the set of answers given by different species facing danger or a real or potential threat, it arises when a danger or threat manifests itself or in the presence of stimuli that indicate one (ambiguous, innate or learned). ${ }^{16}$
The data analysis was performed following the steps proposed by the PTD ${ }^{17}$ Grounded Theory, widely used in the analysis of qualitative information. ${ }^{18}$

After collecting evidence, the coding or data analysis was carried out. ${ }^{19}$ A preparation of qualitative data, data segmentation, coding and grouping of family codes was performed.

The completion of an interview led to a new coding constantly and immediately.

At this stage of data coding the researcher analyzed the transcribed data line by line, thus establishing codes to illustrate the meaning of what was transcribed, using as far as possible the interviewees' words. Even very significant literal expressions of some informants were respected, reflecting, very comprehensively, beliefs and positions, in what is known as "live code". Moreover, as has previously been explained, sampling was theoretical, as it was collected, it analyzed and encoded data and it was decided where it had to be collected and where to find it, in order to explain theory as it emerged. The women's experiences, their beliefs, their lives, were being analyzed and comparing incident to incident, incident to concept and concept to concept, thereby obtaining saturation codes. Among other codes, women's fears, lack of knowledge and information regarding their own bodies and reproductive health were strongly emerging as well as personal improvements and strategies to achieve it. Data collection was extended until the researcher considered it sufficient for understanding the phenomenon studied, which coincided with the 24 people interviewed.

The triangulation of different sources has also been performed with the help of a licensed Atlas.ti version 5.0 software. From each of the analyzed documents (field notebook notes, verbatim transcripts of the interviews) they have been related to the categories and crosscutting with the literature. The Helsinki declaration of ethical principles for research involving human subjects has been followed. All participants were informed and were asked to consent to recording the interviews respecting the anonymity and confidentiality agreement. As a limitation of the study, to point out the difficulty of moving within subjective and personal grounds that sometimes made the discourse difficult due to their embarrassment. 


\section{RESULTS AND DISCUSSION}

After analyzing the discourses it is observed that everything related to menstruation has been "infused" in most informers, deep fears with no scientific or medical basis; fears that due to the lack of knowledge of the women themselves on issues of reproductive health have been passed down from generation to generation until our days. [...] The typical things from before that you cannot wash, that you do not rinse yourself off with cold water ... I was told by the mothers of other friends; my mother did not really tell me much, in fact, she avoided the issue, but the mothers of the other friends told me, 'do not wash with cold water', 'do not get into the shower' 'do not wash your hair' (M9.U.37).

That is, in many cases, they lived all their life in fear, since many of these women maintained these fears as real and almost dogmas; but, as stated, they were not real, although the aim was to protect women.

The origin of these fears is the erroneous beliefs that menstrual blood is incompatible with water and that it is toxic. Women who lived and live with these integrated fears really had a bad time in the face of such harmless situations such as wetting their feet in the days of menstruation. [...] to put your feet into cold water was really bad, so you could not go to the beach, nor to the pool ... that is, that was, you know ?, prohibited... So, do not wash your hair, do not shower (M10.U.48).

It is seen in the testimonies that the feeling of fear was because they did not want anything bad to happen to them, and when they have daughters, they do not want anything bad to happen to their daughters, even their granddaughters. [...] My mother for instance if I had the period she would not let me go to the pool nor the beach or anywhere at all (M6.R.46).

That is, in many cases, they lived in fear all their life, since many of these women internalized these fears as real and almost dogmas; but, as stated, they were not real, but the aim was to protect women.
Menstrual blood has three basic features that make it have a much stronger emotional impact than any other: It is human, spilling outside the control of women and is related to sex and procreation. This could explain the taboos and myths surrounding menstruation. And taboo means forbidden, dangerous, but sometimes has a sacred character at the same time. The menstrual cycle is a feminine fact, as the woman is the dominated sex, myths and taboos do nothing but manifest that situation. ${ }^{6}$

In this sense, it is still observed, even in the twentieth century, the idea of protecting others from menstrual blood in sentences such as: women feel menstruation as a special problem is expressed in some books on gynecology and maternal-child nursing of the nineties in the last century. The menstrual flow, with its normal musky odor, is a source of embarrassment for Western women... women should be careful to protect others from exposing their blood. ${ }^{20}$

\section{Fears related to water use and disease}

It is a set of widespread fears. They are based primarily on the fact that menstrual blood is incompatible with water; therefore, the minimum contact menstruating woman have with water can produce devastating effects on their health. This fear was very present in informers over sixty-five. Nowadays, as has been proven in research, it is still being transmitted in some women, but it has lost a lot of strength. The aim was to protect them from possible diseases or affections. In Figure 1 those conditions that have appeared after the analysis of the speeches are reflected.

The belief in the harmfulness of menstruating women is very old, as it was believed that menstrual blood contained strange, irritating, toxic or poisonous substances. Caias Pliny the second, Pliny the Elder, in his important Natural History work offers an extensive list of Roman beliefs about menstruación ${ }^{21}$ finding in research that many of these ancient false fears are common to women today. 


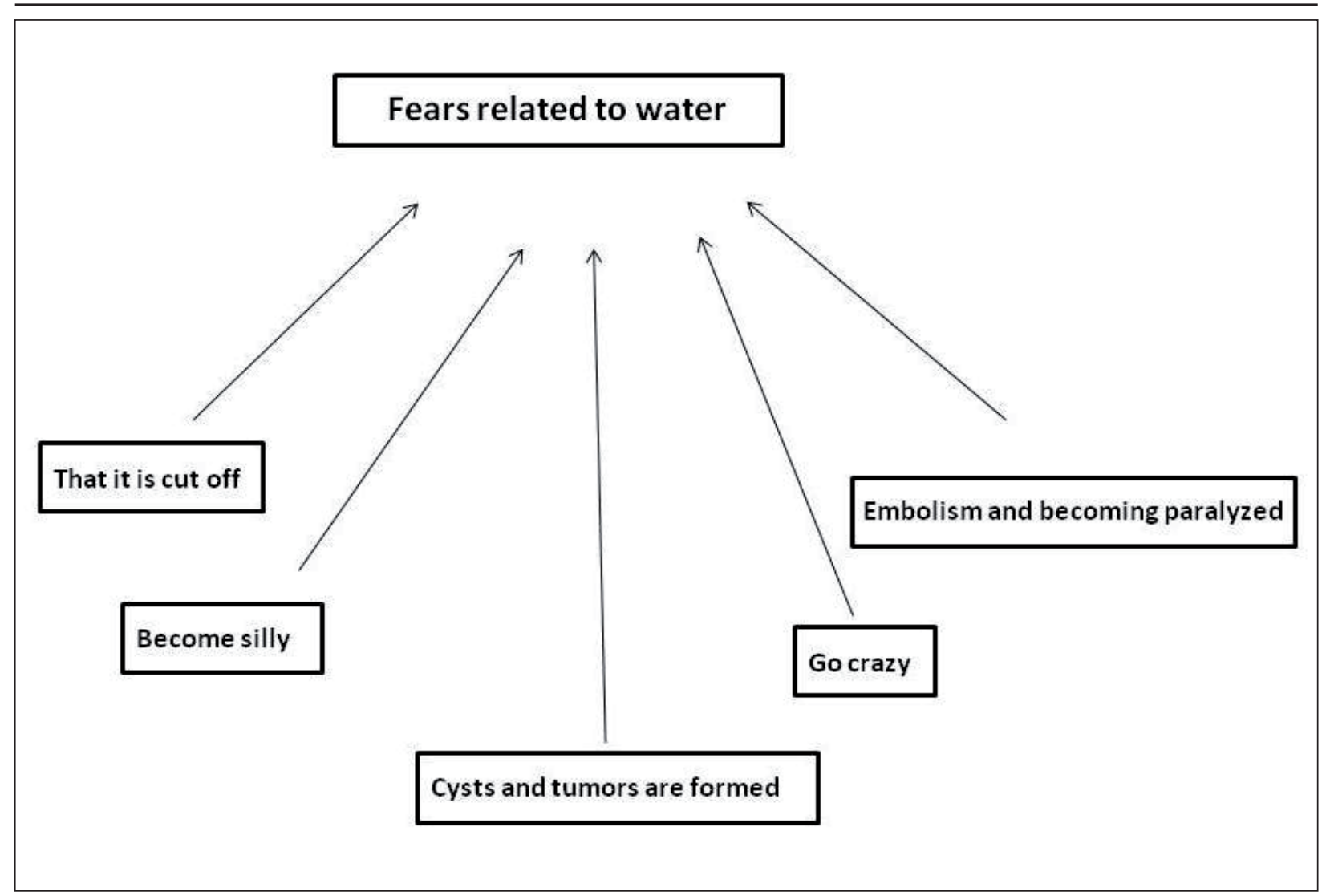

Figure 1- Fears relative to hygiene and menstruation

\section{Fear of menstruation being "cut"}

The origin is that menstrual blood is incompatible with water. Although, as informers have said, due to their relationship with the belief that menstruation produces a "state of heat in the body" which has to be maintained during those days. The main consequences of a "cut" in menstruation is that when it returns it is more painful, that cysts or tumors because blood that has been "curdled" inside the body, and that this could even disappear definitively, with the consequent inability to have children [...] It was previously said not to wash your hair, clean yourself but do not shower [...] (M2.R.31).

[...] Do not rinse with cold water as your menstruation will disappear (M9.U.37).

[...] Do not you to wash your hair because your menstruation will be cut [...] (M8.U.46).

De Beauvoir, in his book "The Second Sex" ${ }^{22}$ states that the moment a woman is capable of giving birth, she becomes impure. He reviews the severe taboos that primitive societies make about girls on their first day of menstruation, such as leaving them exposed on the roof of a house, abandoned in a cabin situated outside the town limits, even not being able to touch nor look at them. Once past this first test, menstrual taboos are less severe but still rigorous and strict. ${ }^{22}$

According to different authors, menstruation should not be seen as something dirty or a sign of inferiority but to turn it into a biological warning of our organism when it breaks the chronological cycle. $^{23}$

\section{Fear of going crazy}

It consists of the fear that menstruating woman can go crazy if they have a shower or bathe during menstruation. It is closely related to the previous fear. [...] In the village there was a woman who was bathing during her period and suddenly jay! ran out of her house naked like a mad woman, because that is terrible, that woman went crazy, lost her head because of doing that, I'll tell my daughter [...] (M4.R.42). The fact of giving an example of an actual case is common in informers to which they associate this evil because of having washed their 
hair or showered during menstruation, thus the fear of the community is strengthened: [...] do not you wash your hair because your menstruation will be cut [...] (M8.U.46)

As shown in the results, there are numerous fears and misconceptions regarding menstruation without any scientific or biological basis that demonstrates the complete ignorance of women themselves about menstruation and the lack of research.

"The same feminist literature suffers from lack of clarity in this regard, firstly disregarding this reality in the lives of many women, for the sake of equality we did not take into account this difference, or directly denying the influence or determinants of the altered menstrual cycle, for fear that the lives of women were considered inferior or conditioned by the fact of menstruation. ${ }^{23: 133}$

\section{Fear of suffering an embolism or becoming paralytic}

Fear also related to the fact of wetting one's hair [...] if I washed my hair when I had my period I could have, say, an embolism or something like that and be paralyzed. It is what I was told. If I washed my hair when I had my period [...] (M6.R.46).

Some young informants refer to how their mothers have taught them: [...] When I was twelve or thirteen so that I would know that I could not wash my hair when I had my period [...] (M23.U.24).

The fear that menstruation can be cut off by having sour or cold foods was observed in some informants, young and old, [...] You could not bathe, you could not have things with vinegar nor oranges during their season ...no sour things ... nor be scared because it would be cut off [...] (M11.R 84).

[...] You could not have ice cream because your period would be cut off. (M16.R.23).

Fear was repeated that menstruation is cut off or you go crazy for the slightest contact with water. [...] That was, to be exact, no daughter, no, you cannot wash your hair! [...] (M22.U.77).

According to other authors there are a great number of topics, misconceptions, referring to women, which are transmitted from generation to generation without any scientific basis with undoubted impact on their health which confirms that the lack of studies, research and fact-finding by professionals has frequently led to a transmission of inappropriate knowledge. ${ }^{25}$

Nurses play an important role in the eradication of these misconceptions by promoting health through specific health education programs that affect these erroneous beliefs and eliminate them as has been demonstrated in research. Despite the actions and campaigns devoted to health education on physiological changes in women many false millennial beliefs regarding menstruation are still present in our days. ${ }^{26-27}$

\section{CONCLUSIONS}

The main fears obtained in research regarding menstruation refer to hygiene that forbids menstruating women the slightest contact with water due to the risk of disease (stroke, paralysis, dementia). These prohibitions may originate in the necessary control of water as a scarce resource in the areas studied. Therefore, the above prohibitions relating to menstruation constituted a form of discrimination and social, political and religious segregation, a way of manipulating women whose main purpose in many cases was economic.

The eldest women are the ones who have more fears regarding water hygiene during menstruation; contact being relegated to the bare minimum. Even today, many women of all ages in both rural and urban contexts remain subject to false fears and pressures, like, "going crazy" because of having a shower during menstruation. With regard to mothers and childless women there was no significant difference.

It has been shown that the higher the informer's educational level, the fewer the fears shown regarding menstruation. Lack of knowledge of women about reproductive health and "control of their bodies" is highlighted.

Nursing in a fundamental discipline for health promotion, developing education programs about the menstrual cycle for women so that they understand menstruation as a normal physiological process without fear or false pressures.

\section{REFERENCES}

1. Vega VC. Adaptación Argentina de un inventario para medir identidad de rol de género. Rev Latino- 
ame Psicol [Internet]. 2007 [access 2013 Oct 15]; 39(3):537-46. Disponible en: http://www.redalyc. org $/$ articulo.oa?id $=80539307$

2. Botello Hermosa A, Casado Mejía R. La menopausia y sus representaciones sociales: importancia del abordaje desde la Educación para la salud. Rev Enferm UERJ [Internet]. 2014 Mar-Abr [access 2014 Sep 15]; 22(2):182-6. Disponible en: http:/ / www. facenf.uerj.br/v22n2/v22n2a06.pdf

3. Gómez Amor J, Martínez Selva JM. Psicobiología del ciclo menstrual. Madrid (ES): Universidad Nacional de Educación a Distancia; 1991.

4. Leininger M. Transcultural nursing; concepts, theories, research and practice. In: Leininger $M$, McFarland Mr, editors). Transcultural nursing: concepts, theories, research and culture. $3^{\text {a }}$ ed. Toronto (CA):McGraw.Hill; 2002. p.77-98.

5. Chávez Álvarez RE, Arcaya Moncada MJ, Garcia Arias G, Surca Rojas TC. Rescatando el autocuidado de la salud durante el embarazo, el parto y al recién nacido: representaciones sociales de mujeres de una comunidad nativa en Perú. Texto Contexto Enferm [Internet]. 2007 Out-Dez [access 2014 Sep 22]; 16(4):680-7. Disponible en http:/ / www.redalyc. org/articulo.oa?id=71416412

6. Sau V. Reflexiones feministas para principios de siglo. Madrid (ES): Horas y horas; 2000.

7. Moscovici S. Psicología social II: pensamiento y vida social. Barcelona (ES): Paidós; 1993

8. Pelcastre-Villafuerte B, Garrido-Latorre F, de LeónReyes V. Menopausia: representaciones sociales y prácticas. Salud Pública Méx [Internet]. 2001 [access 2013 Oct 15]; 43(5):408-14. Disponible en: http:// bvs.insp. $\mathrm{mx} / \mathrm{rsp} /$ articulos/articulo.php?id $=000318$

9. Billig M, Condor S, Edwards D, Gane M, Middleton D, Radley A. Ideological dilemas: A social psychology of everyday thinking. Londres (UK): Sage; 1988.

10. Candreva A, Paladino C. Cuidado de la salud: el anclaje social de su construcción - estudio cualitativo. Univ Psychol Bogotá [Internet]. 2005 [access 2014 Sep 20]; 4(1):55-62. Disponible en: http://sparta. javeriana.edu.co/psicologia/publicaciones/ actualizarrevista/archivos/V4N106cuidado_de_ la_salud.pdf

11. Campo-Redondo M, Labarca Reverol C. La teoría fundamentada en el estudio empírico de las representaciones sociales: un caso sobre el rol orientador del docente. Opción [Internet]. 2009 [access 2014 Sep 20]; 25(60):41-54. Disponible en: https:/ / docs.google.com/a/ustea.net/viewer?url=http:/ / redalyc.uaemex.mx/pdf/310/31012531004.pdf

12. Montero I, Orfelio L. A guide for naming research studies in Psychology. Int J Clin Health Psychol. 2007; 7(3):847-62.
13. Ulin PR, Robinson ET, Tolley EE. Investigación aplicada en salud pública: métodos cualitativos. Washington (US): Organización Panamericana de la Salud; 2006.

14. Vivar C, Arantzamendi G, López Dicastillo M, Gordo C. La teoría fundamentada como metodología de investigación cualitativa en enfermería. Index Enferm [Internet]. 2010 [access 2013 Dic 15]; 19(4):283-8. Disponible en: http://www.index-f. com/index-enfermeria/v19n4/7175r.php

15. Tong A, Sainsbury P, Craig J. Consolidated criteria for reporting qualitative research (COREQ): a 32item checklist for interviews and focus group. Int J Qual Health Care 2007; 19(6):349-57.

16. Becerra-García AM, Madalena AC, Célio E, Rodríguez-Rico JL, Dias H, Bassi A, ChagasBloes DA, Morato S. Ansiedad y miedo: su valor adaptativo y maladaptaciones. Rev Latino-am Psicol [Internet]. 2007 [access 2014 Mar 5]; 39(1):75-81. Disponible en http://www.redalyc.org/articulo. oa?id=80539107

17. De la Cuesta-Benjumea C. La teoría fundamentada como herramienta de análisis. Cul Cuid [online]. 2006 [acceso 2014 Sep 23]; 20(2):136-40. Disponible en: http://culturacuidados.ua.es/enfermeria/ article/view/257/513

18. Strauss AL, Corbin J. Bases de la investigación cualitativa: técnicas y procedimientos para desarrollar La teoría fundamentada. Medellín (CO): Editorial Universidad de Antioquia; 2002.

19. Lima SBS, Leite JL, Erdmann AL, Prochnow AG, Stipp MAC, García VRRL. La teoría fundamentada en datos: un camino a la investigación en enfermería. Index Enferm [Internet]. 2010 [access 2013 Nov 19] 19(1):55-9. Disponible en: http:/ / scielo.isciii.es/ scielo.php?pid=S1132$12962010000100012 \&$ script $=$ sci_arttext

20. Dickason EJ, Silverman BL, Schult MO. Enfermería MaternoInfantil. Madrid (ES): Mosby; 1995. p.59.

21. Manzanero Cano F. Historia natural: obra completa de Cayo Plinio Segundo. Madrid (ES): Gredos; 2010.

22. De Beauvoir. El segundo sexo. $2^{\mathrm{a}}$ ed. Madrid (ES): Cátedra; 2008.

23. Valls-Llobet C. Mujeres, salud y poder. Madrid (ES): Cátedra; 2009.

24. Douglas M. Pureza y peligro: un análisis de los conceptos de contaminación y tabú. Buenos Aires (AR): Nueva Visión; 2007.

25. Macías Seda J, Gómez Salgado J. Mujer y salud. Madrid (ES): Fuden; 2008.

26. Pereira A. O imaginario sobre o trábalho dos géneros profissionais: a vertente do sofrimento e do prazer no trábalo da(o) enfermeira(o). Texto Contexto Enferm. 2002 Jan-Abr; 11(1):105-20. 
27. Rus García A. Óvulos rojizos. Gac Sanit [Internet]. en: http:/ / www.scielosp.org/scielo.php?script=sci_ 2009 Jun [access 2013 Nov 17]; 23(3):256. Disponible arttext\&pid=S0213-91112009000300021\&lng=en

Universidad de Sevilla

C/ Avenzoar n 6

CP 41009 - Sevilla, España

E-mail: abotello@us.es 